Sains Malaysiana 49(5)(2020): 989-994

http://dx.doi.org/10.17576/jsm-2020-4905-03

\title{
Cytotoxic Triterpenoids from the Stem Barks of Dysoxylum arborescens and Dysoxylum excelsum against MCF-7 Breast Cancer Cell
}

(Triterpenoid Sitotoksik daripada Kulit Batang Dysoxylum arborescens dan Dysoxylum excelsum terhadap Sel Kanser Payudara MCF-7)

\section{Achmad Zainud Din, Sylvia RachmaWati Meilanie, DarWati, KurniaWAn, Nurlelasari,Tati Herlina, ADRIAN RIZKY SAPUTRA, JAMALUDIN Al ANSHORI \& TRI MAYANTI*}

\section{ABSTRACT}

Three triterpenoids, taraxerone (1) and 18-epi-taraxerol (2), and masticadienolic acid (3) were isolated for the first time from the stem barks of Dysoxylum arborescens and Dysoxylum excelsum, respectively. Isolation of the compounds was achieved by various extraction and chromatography column techniques, while their chemical structures were elucidated based on spectroscopic data and literature comparison. Compounds 1, 2, and $\mathbf{3}$ were found to show inhibitory activity against MCF-7 breast cancer cells with $I_{50}$ values 792.9, 59.6, and $3.5 \mu M$ correspondingly.

Keywords: Dysoxylum arborescens; Dysoxylum excelsum; MCF-7; triterpenoids

ABSTRAK

Tiga triterpenoid, tarakseron (1) dan 18-epi-tarakserol (2), asid mastikadienolat (3) telah dipisahkan daripada kulit batang Dysoxylum excelsum dan Dysoxylum arborescens buat pertama kali. Sebatian 1, 2 dan 3 dipencilkan menggunakan pelbagai teknik lajur ektraksi dan kromatografi, sementara penentuan strukturnya menggunakan bantuan data spektroskopi dan perbandingan dengan sebatian yang pernah dilaporkan sebelumnya. Aktiviti sitotoksik sebatian 1, 2 dan 3 terhadap sel kanser payudara MCF-7 menunjukkan perencatan dengan nilai IC ${ }_{50}$ masing-masing 792.9, 59.6 dan $3.5 \mu M$.

Kata kunci: Dysoxylum arborescens; Dysoxylum excelsum; $M C F-7$; triterpenoid

\section{INTRODUCTION}

Dysoxylum arborescens and Dysoxylum excelsum are members family of Meliaceae which are naturally members distributed in Asia - China, Taiwan, Andaman and Nicobar Islands, Malaysia, Indonesia to New Guinea, Northeast Australia, Solomon Islands, Vanuatu, India, and Southeast Asia (Mabberley 2008). Various types of compounds have been isolated from this genus, such as chromone alkaloids (Morita et al. 2014) sesquiterpenoids (Nugroho et al. 2015), diterpenoids (Duh et al. 2000) limonoids, and triterpenoids (Han et al. 2014). Some of them were reported to have interesting biological activities (Laksmi et al. 2009) such as cytotoxic sesquiterpenoids (Nugroho et al. 2015), anticancer diterpenoids (Fujioka et al. 1998), cytotoxic tirucallane triterpene (Kurimoto et al. 2011; Mohamad et al. 1999), cytotoxic triterpenoids and limonoids (Han et al. 2015; Zhou et al. 2015), antibacterial triterpenoids (Hu et al. 2014; Liu et al. 2011) and antibacterial steroids (Wah et al. 2013). As the tetracyclic and pentacyclic terpenoids typical compounds in the family of Meliaceae showed interesting bioactivities, herein we reported for the first time, the isolation and structural elucidation of two cytotoxic triterpenoids from the stem barks of $D$. arborescens and one from $D$. excelsum against MCF-7 breast cancer cells.

\section{MATERIALS AND METHODS}

GENERAL

Melting points were measured on Mettler Toledo MP50 apparatus and were uncorrected. Mass spectra were obtained from Water HR-QToF-MS, The IR spectra were recorded on Perkin-Elmer spectrum-100 FT-IR in $\mathrm{KBr}$ pellets. The ${ }^{1} \mathrm{H}$ and ${ }^{13} \mathrm{C}$-NMR spectra were measured on JEOL JNM ECA-500 spectrometer using TMS as internal standard. Column chromatography was conducted on silica gel 60 (Merck, Germany) and RP-18 silica gel (Merck, Germany). TLC plates were precoated with silica gel $\mathrm{GF}_{254}$ (Merck, Germany, $0.25 \mathrm{~mm}$ ) and detection was achieved by spraying with $\mathrm{H}_{2} \mathrm{SO}_{4}$ in ethanol $(10 \%$, $\mathrm{v} / \mathrm{v}$ ), followed by heating.

\section{PLANT MATERIALS}

The stem barks of $D$. arborescens were collected in Bogor Botanical Garden (Collection Number: III.E.64), Bogor, West Java Province, Indonesia in July 2014 
while the stem barks of D. excelsum were in June 2016 (Collection Number: III.F.67). The plants were identified by staff of Bogor Botanical Garden, Indonesian Science Institute.

\section{EXTRACTION AND ISOLATION}

The dried stem barks of $D$. arborescens $(1.4 \mathrm{~kg})$ were extracted with methanol exhaustively $(5 \mathrm{~L})$ at room temperature for 3 days. After removal of the solvent under reduced pressure, the viscous methanolic extract $(61.1 \mathrm{~g})$ was first suspended in $\mathrm{H}_{2} \mathrm{O}$ and then partitioned with $n$-hexane and EtOAc, successively. The ethyl acetate crude (12.4 g) was subjected to chromatography column over silica gel using a gradient elution of $n$-hexane, EtOAc, and $\mathrm{MeOH}$ to afford 16 fractions (A$\mathrm{P})$. Fraction $\mathrm{C}(230 \mathrm{mg})$ was further purified on silica gel chromatography column, with mobile phase of $n$-hexane:dichloromethane $(10: 0-2: 8, \mathrm{v} / \mathrm{v})$ to afford 4 fractions (C1-C4). The fraction of $\mathrm{C} 2$ gave compound $\mathbf{1}$ $(12 \mathrm{mg})$ and $\mathrm{C} 3$ gave compound $2(11 \mathrm{mg})$.

The dried stem barks of $D$. excelsum $(2.7 \mathrm{~kg})$ were treated in a manner similar to that of $D$. arborescens to produce $300 \mathrm{~g}$ of crude extract. The ethyl acetate-soluble fraction $(30.0 \mathrm{~g})$ was subjected to chromatography column over silica gel using a gradient elution of $n$-hexane and EtOAc to give 8 fractions (F1-F8). Fraction F7 (5.8 g) was then separated on silica gel chromatography column and eluted with the mixtures of $n$-hexane/EtOAc (10:0-8:2, v/v) to give 3 fractions (F7a-F7c). Further purification was applied to the fraction of F7c (silica gel, $n$-hexane:acetone (10:0-7:3, $\mathrm{v} / \mathrm{v})$ to yield 4 fractions $(\mathrm{F} 7 \mathrm{c} 1-\mathrm{F} 7 \mathrm{c} 4)$. The fraction of F7c2 gave compound 3 (20 mg).

Taraxerone (1) White needle-like crystals; m.p ${ }^{\circ} \mathrm{C}$ : 239.8-241.3; IR (KBr) $v_{\text {max }} \mathrm{cm}^{-1}: 3048,2930,1709,1640$, 1376; ${ }^{1} \mathrm{H}-\mathrm{NMR}\left(\mathrm{CDCl}_{3}, 500 \mathrm{MHz}\right)$, (Table 1); ${ }^{13} \mathrm{C}-\mathrm{NMR}$ $\left(\mathrm{CDCl}_{3}, 125 \mathrm{MHz}\right)$, (Table 1); HR-ToF-MS (ESI) $\mathrm{m} / \mathrm{z}$ 447.3669 $[\mathrm{M}+\mathrm{Na}]^{+}$(calc. $\mathrm{m} / \mathrm{z}$ for $\mathrm{C} 30 \mathrm{H} 48 \mathrm{ONa} 447.3597$ ).

18-epi-taraxerol (2) White needle-like crystals; m.p ${ }^{\circ} \mathrm{C}$ : 282.3-283.0; IR (KBr) $v_{\max } \mathrm{cm}^{-1}: 3486,3054$, 2934, 1641, 1382; ${ }^{1} \mathrm{H}-\mathrm{NMR}\left(\mathrm{CDCl}_{3}, 500 \mathrm{MHz}\right)$, (Table 1); ${ }^{13} \mathrm{C}-\mathrm{NMR}\left(\mathrm{CDCl}_{3}, 125 \mathrm{MHz}\right)$, (Table 1), HR-ToF-MS (ESI) $\mathrm{m} / \mathrm{z} 449.3648[\mathrm{M}+\mathrm{Na}]+$ (calc. $\mathrm{m} / \mathrm{z}$ for $\mathrm{C} 30 \mathrm{H} 50 \mathrm{ONa} 449.3764$ ).

Masticadienolic acid (3) White needle-like crystals; m.p ${ }^{\circ} \mathrm{C}$ : 128.4-168.0; IR (KBr) $v_{\max } \mathrm{cm}^{-1}$ : 3420, 2955, 1680, 1620, 1360; ${ }^{1} \mathrm{H}-\mathrm{NMR}\left(\mathrm{CDCl}_{3}, 500 \mathrm{MHz}\right)$, (Table 1); ${ }^{13} \mathrm{C}-\mathrm{NMR}\left(\mathrm{CDCl}_{3}, 125 \mathrm{MHz}\right)$, (Table 1), HR-ToF-MS (ESI) $m / z 455.3831[\mathrm{M}-\mathrm{H}]^{-}$.

\section{BIOASSAY OF CYTOTOXIC ACTIVITIES}

MTT assay protocol was following a method reported by Mosmann with some modifications (Mosmann 1983). The MCF-7 cells were seeded into 96-well plates at an initial cell density of approximately $3 \times 10^{4}$ cells $\mathrm{cm}^{-3}$. After $24 \mathrm{~h}$ of incubation for cell attachment and growth, varying concentrations of samples were added. The compounds added were first dissolved in DMSO at the required concentration. Subsequent three desirable concentrations were prepared using PBS (phosphoric buffer solution, $\mathrm{pH}=7.30-7.65)$. Control wells received only PBS and DMSO. The assay was terminated after $48 \mathrm{~h}$ incubation period by adding MTT reagent (3-(4,5-dimethylthiazol-2-yl)-2,5-diphenyltetrazolium bromide). The incubation was then continued for another $4 \mathrm{~h}$, in which the MTT-stop solution containing SDS (sodium dodecyl sulphate) was added and terminated by another $24 \mathrm{~h}$ incubation. Optical density was read by using a micro plate reader at $550 \mathrm{~nm}$. $\mathrm{IC}_{50}$ values were calculated from the plotted graph of percentage live cells compared to control (\%) versus the tested concentration of compounds $(\mu \mathrm{M})$.

\section{RESULTS AND DISCUSSION}

Compound 1 was obtained as a white needle-like crystals; m.p. $239.8-241.3{ }^{\circ} \mathrm{C}$. The HR-ToF-MS spectrum of 1 exhibited a quasi molecular ion with sodium at $\mathrm{m} / \mathrm{z}$ 447.3675 (calc. $m / z$ for $\mathrm{C}_{30} \mathrm{H}_{48} \mathrm{ONa} 447.3597$ ). Supported by its ${ }^{1} \mathrm{H}$ and ${ }^{13} \mathrm{C}$ NMR data (Table 1 ), the MS showed the molecular formula $\mathrm{C}_{30} \mathrm{H}_{48} \mathrm{O}$ with 7 degrees of unsaturation. The IR spectrum showed absorption peaks at $3048\left(\mathrm{C}-\mathrm{H} \mathrm{sp}^{2}\right), 2930(\mathrm{C}-\mathrm{H}), 1709(\mathrm{C}=\mathrm{O}), 1640(\mathrm{C}=\mathrm{C})$, and $1376 \mathrm{~cm}^{-1}$ (gem dimethyl). The ${ }^{1} \mathrm{H}-\mathrm{NMR}$ spectrum exhibited the presences of eight tertiary methyl groups which resonated at $\delta_{\mathrm{H}}: 0.91,0.83,0.91,0.95,1.06,1.08$, 1.08 and 1.14 ppm assigned to H-26, H-28, H-30, H-29, $\mathrm{H}-24, \mathrm{H}-23, \mathrm{H}-25$ and $\mathrm{H}-27$, respectively. The presence of all methyl groups as singlet supported the fact that all methyl groups in compound $\mathbf{1}$ are attached to quaternary carbons. Double doublet signal appeared at $\delta_{\mathrm{H}} 1.02(\mathrm{~J}=$ $4.5 \mathrm{~Hz}$ ) showed the presence of methine $s p^{3}$ while another double doublet signal at $5.56(J=3.2 \mathrm{~Hz})$ confirmed the presence of one olefinic proton at $\mathrm{H}-15$ coupled with the protons of $\mathrm{H}-16$. The ${ }^{1} \mathrm{H}-\mathrm{NMR},{ }^{13} \mathrm{C}-\mathrm{NMR}$ and DEPT (SI.5) spectra of 1 showed 30 resonances, assigned to eight methyl groups, ten methylene $s p^{3}$ groups, three methines $s p^{3}$, one methine $s p^{2}$, six quaternary $s p^{3}$ carbons and two quaternary $s p^{2}$. A carbonyl group was observed at $\delta_{\mathrm{C}} 217.8$. The double bond was represented by two singlets at $\delta_{\mathrm{C}} 157.8$ and 117.4 for carbons $\mathrm{C}-14$ and $\mathrm{C}-15$, respectively. The ${ }^{1} \mathrm{H}$ and ${ }^{13} \mathrm{C}-\mathrm{NMR}$ together with HR-ToF-MS data, suggested the presence of a typical pentacyclic triterpene skeleton. The structure elucidation of compound 1 was supported by HMQC, COSY, and HMBC (SI.6-8) spectra as well as comparing with those reported previously (Ragasa et al. 2014) (SI.22 and 23). Thus compound $\mathbf{1}$ was identified as taraxerone.

Compound $\mathbf{2}$ was obtained as a white needle-like crystals; m.p ${ }^{\circ}$ C. 282.3-283.0. The HR-ToF-MS spectrum of 2 exhibited a quasi molecular ion with sodium at $\mathrm{m} / \mathrm{z}$ 449.3658 (calc. $m / z$ for $\mathrm{C}_{30} \mathrm{H}_{50} \mathrm{ONa} 449.3764$ ). Supported by its ${ }^{1} \mathrm{H}$ and ${ }^{13} \mathrm{C}-\mathrm{NMR}$ data (Table 1 ), the MS showed the molecular formula of $\mathrm{C}_{30} \mathrm{H}_{50} \mathrm{O}$ with 6 degrees of unsaturation. The IR spectrum showed absorption peaks at $3486(\mathrm{O}-\mathrm{H}), 3054(\mathrm{C}=\mathrm{C}), 2934(\mathrm{C}-\mathrm{H}), 1641(\mathrm{C}=\mathrm{C})$, 
and $1382 \mathrm{~cm}^{-1}$ (gem dimethyl). The ${ }^{1} \mathrm{H}-\mathrm{NMR}$ spectrum exhibited the presences of eight methyl groups which resonated at $\delta_{\mathrm{H}}: 0.82,0.83,0.91,0.92,0.94,0.96,0.99$, and $1.10 \mathrm{ppm}$ assigned to $\mathrm{H}-24, \mathrm{H}-28, \mathrm{H}-27, \mathrm{H}-30, \mathrm{H}-25$, $\mathrm{H}-29, \mathrm{H}-23$ and $\mathrm{H}-26$ respectively. The presence of all methyl groups as singlet supported the fact that all methyl groups in compound $\mathbf{2}$ are attached to quaternary carbons. Double doublet signal appeared at $\delta_{\mathrm{H}} 0.97(\mathrm{~J}=5$ $\mathrm{Hz}$ ) showed the presence of methine $s p^{3}$, while another double doublet signal appeared at $5.55(J=3.0 \mathrm{~Hz})$ confirmed the existence of one olefinic proton at $\mathrm{H}-15$ coupled with the protons of $\mathrm{H}-16$. The ${ }^{1} \mathrm{H}$, and ${ }^{13} \mathrm{C}-\mathrm{NMR}$ spectra of 2 showed 30 resonances, assigned to eight methyl groups, ten methylene $s p^{3}$ groups, four methines $s p^{3}$, one methine $s p^{2}$, six quaternary $s p^{3}$ carbons and one quaternary $s p^{2}$. All of these spectra were similar with 1, other than the substituent at position 3 . The position of the carbonyl group in compound $\mathbf{1}$ is replaced by the hydroxy group in compound $\mathbf{2}$ which is showed in ${ }^{1} \mathrm{H}-\mathrm{NMR}$ of compound 2 at $3.21 \mathrm{ppm}(1 \mathrm{H}, d, J=7 \mathrm{~Hz})$ and ${ }^{13} \mathrm{C}-\mathrm{NMR}$ at 218.8 and $79.1 \mathrm{ppm}$ (each for compound 1 and 2, respectively). The HMBC crosspeak (SI.14) from methylene protons $\mathrm{H}-2\left(\delta_{\mathrm{H}} 1.60\right.$ and 1.57$)$ and $\mathrm{H}-1\left(\delta_{\mathrm{H}}\right.$ 1.61 and 0.96$)$ to the oxymethine at $\delta_{\mathrm{C}} 79.1$, indicated the presence of a hydroxyl group at $\mathrm{C}-3$. Methine proton at $\mathrm{H}-18\left(\delta_{\mathrm{H}} 0.97 \mathrm{ppm}, 1 \mathrm{H}, \mathrm{dd}, J=5\right)$ was indicated $\mathrm{H}-18$ equatorial and thus the conformation was $\alpha$-oriented. Supporting data of HSQC (SI.13) and HMBC Spectra (SI.14) as well as comparison of the NMR data of 2 with 18-epi-taraxerol (Mejin 2009) (SI.22 and 23) showed that the structures of the two compounds were very similar. Therefore compound $\mathbf{2}$ was identified as 18-epi-taraxerol.
Compound $\mathbf{3}$ was obtained as a white needle-like crystals, m.p ${ }^{\circ} \mathrm{C}$ 128.4-131.0. The HR-ToF-MS spectrum showed $[\mathrm{M}-\mathrm{H}]^{-}$at $\mathrm{m} / \mathrm{z} 455.3831$ (calc. 455.3531). Supported by its ${ }^{1} \mathrm{H}$ and ${ }^{13} \mathrm{C}-\mathrm{NMR}$ data (Table 1 ), the MS showed the molecular formula of $\mathrm{C}_{30} \mathrm{H}_{48} \mathrm{O}_{3}$ and thus required seven degrees of unsaturation. The IR spectrum showed absorption peaks at $3420(\mathrm{O}-\mathrm{H}), 2955(\mathrm{C}-\mathrm{H})$, $1680(\mathrm{C}=\mathrm{O}), 1620(\mathrm{C}=\mathrm{C})$ and $1360 \mathrm{~cm}^{-1}$ (gem dimethyl). The ${ }^{1} \mathrm{H}-\mathrm{CMR}$ spectrum exhibited the presences of seven methyl groups, five singlets which resonated at $\delta_{\mathrm{H}}: 0.76$, 0.83, 0.91, 0.93 and 0.97 ppm for H-19, H-29, H-18, H-28 and $\mathrm{H}-30$, respectively. A doublet and a singlet signal was observed at $\delta_{\mathrm{H}} 0.89$ and $1.91 \mathrm{ppm}$, respectively, which were assigned to $\mathrm{H}-21$ and $\mathrm{H}-27$ that attached to a quaternary $s p^{2}$ carbon. The ${ }^{1} \mathrm{H},{ }^{13} \mathrm{C}-\mathrm{NMR}$ and $\mathrm{HSQC}$ (SI.19) spectra of $\mathbf{3}$ showed 30 resonances, assigned to seven methyl groups, nine methylene $s p^{3}$ groups, four methines $s p^{3}$, four quaternary $s p^{3}$ carbons, two quaternary $s p^{2}$ carbons, two methylene $s p^{2}$ groups, one oxygenated methine $s p^{2}$ and one carbonyl carbon. The position of carbons and protons was confirmed by HMBC (SI.20) and ${ }^{1} \mathrm{H}-{ }^{1} \mathrm{H}$ COSY spectra (SI.21). The structure of the euphane/tirucallane tetracyclic system (A, B, C and D) was determined by $\mathrm{HMBC}$ crosspeaks from $\mathrm{H}-18\left(\delta_{\mathrm{H}}\right.$ $0.91)$ to the $\mathrm{C}-12\left(\delta_{\mathrm{C}} 33.9\right), \mathrm{C}-13\left(\delta_{\mathrm{C}} 43.6\right), \mathrm{C}-17\left(\left(\delta_{\mathrm{C}} 52.9\right)\right.$ and $\mathrm{H}-30\left(\delta_{\mathrm{H}} 0.97\right)$ to the $\mathrm{C}-8\left(\delta_{\mathrm{C}} 146.2\right), \mathrm{C}-14\left(\delta_{\mathrm{C}} 51.3\right)$, C-15 $\left(\delta_{\mathrm{C}} 34.1\right)$ (SI.20). Furthermore, the HMBC crosspeak of $\mathrm{CH}_{3}-21$ to $\mathrm{C}-20\left(\delta_{\mathrm{C}} 36.2\right)$ required that the side chain was connected to $\mathrm{C}-20$. Based on the literature data reported previously by Makino et al. (2003) and Unang et al. (2019) (SI.22 and 23), compound 3 was identified as masticadienolic acid.
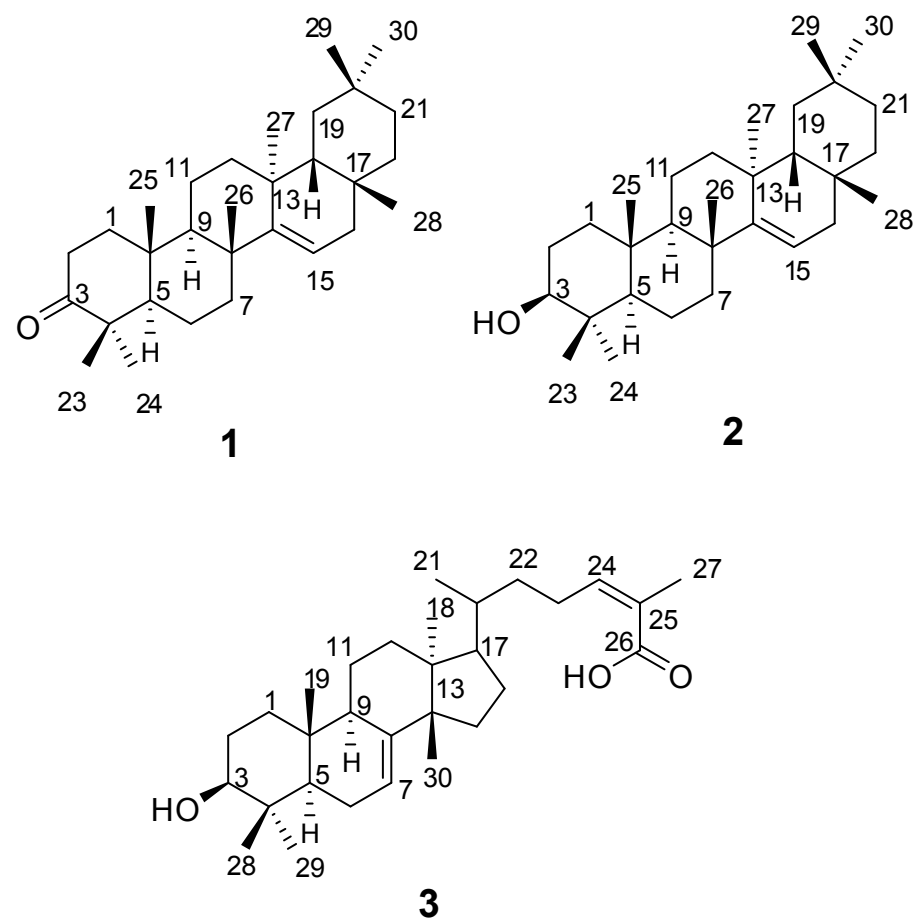

FIGURE 1. Structures of Compounds 1, 2, and $\mathbf{3}$ 
TABLE 1. NMR Data (500 MHz for ${ }^{1} \mathrm{H}$ and $125 \mathrm{MHz}$ for ${ }^{13} \mathrm{C}$, in $\mathrm{CDCl}_{3}$ ) for 1, taraxerone, 2, 18-epi-taraxerol, and 3, masticadienolic acid

\begin{tabular}{|c|c|c|c|c|c|c|}
\hline & & 1 & & 2 & & 3 \\
\hline Position & $\begin{array}{l}{ }^{13} \mathrm{C} \text { NMR } \\
\delta \mathrm{c}\end{array}$ & $\begin{array}{l}{ }^{1} \mathrm{H} \text { NMR } \\
\delta_{\mathrm{H}}(\text { Int., mult, } J=\mathrm{Hz})\end{array}$ & $\begin{array}{l}{ }^{13} \mathrm{C} \mathrm{NMR} \\
\delta \mathrm{c}\end{array}$ & $\begin{array}{l}{ }^{1} \mathrm{H} \text { NMR } \\
\delta_{\mathrm{H}} \text { (Int., mult, } J=\mathrm{Hz} \text { ) }\end{array}$ & $\begin{array}{l}{ }^{13} \mathrm{C} \text { NMR } \\
\delta \mathrm{c}\end{array}$ & $\begin{array}{l}{ }^{1} \mathrm{H} \text { NMR } \\
\delta_{\mathrm{H}} \text { (Int., mult, } \\
J=\mathrm{Hz} \text { ) }\end{array}$ \\
\hline 1 & 38.5 & $1.87 ; 1.36(2 \mathrm{H}, \mathrm{m})$ & 37.7 & $1.61 ; 0.96(2 \mathrm{H}, \mathrm{m})$ & 31.4 & $1.47 ; 1.39(2 \mathrm{H}, \mathrm{m})$ \\
\hline 2 & 34.3 & $2.57 ; 2.33(2 \mathrm{H}, \mathrm{m})$ & 27.1 & $1.60 ; 1.57(2 \mathrm{H}, \mathrm{m})$ & 25.5 & $1.95 ; 1.63(2 \mathrm{H}, \mathrm{m})$ \\
\hline 3 & 217.8 & - & 79.0 & $3.21(1 \mathrm{H}, \mathrm{dd}, 7)$ & 76.5 & $3.46(1 \mathrm{H}, \mathrm{s})$ \\
\hline 4 & 47.7 & - & 38.7 & - & 37.5 & - \\
\hline 5 & 55.9 & $1.34(1 \mathrm{H}, \mathrm{m})$ & 55.5 & $0.79(1 \mathrm{H}, \mathrm{dd}, 11)$ & 44.7 & $1.76(1 \mathrm{H}, \mathrm{m})$ \\
\hline 6 & 20.1 & $1.56 ; 1.57(2 \mathrm{H}, \mathrm{m})$ & 18.7 & $1.61 ; 1.48(2 \mathrm{H}, \mathrm{m})$ & 24.0 & $2.13 ; 1.91(2 \mathrm{H}, \mathrm{m})$ \\
\hline 7 & 35.2 & $1.35 ; 1.34(2 \mathrm{H}, \mathrm{m})$ & 41.3 & $1.36 ; 2.05(2 \mathrm{H}, \mathrm{dd}, 13)$ & 118.0 & $5.25(1 \mathrm{H}, \mathrm{s})$ \\
\hline 8 & 39.0 & - & 38.9 & - & 146.2 & - \\
\hline 9 & 48.8 & $1,50(1 \mathrm{H}, \mathrm{m})$ & 49.2 & $1.43(1 \mathrm{H}, \mathrm{m})$ & 49.0 & $2.30(1 \mathrm{H}, \mathrm{bd}, 11)$ \\
\hline 10 & 35.9 & - & 37.9 & - & 34.8 & - \\
\hline 11 & 17.6 & $1.54 ; 1.67(2 \mathrm{H}, \mathrm{m})$ & 17.4 & $1.65 ; 1.48(2 \mathrm{H}, \mathrm{m})$ & 18.1 & $1.52 ; 1.47(2 \mathrm{H}, \mathrm{m})$ \\
\hline 12 & 37.8 & $1.64 ; 1.92(2 \mathrm{H}, \mathrm{dd}, 11.7)$ & 33.6 & $1.60 ; 1.54(2 \mathrm{H}, \mathrm{m})$ & 33.9 & $1.78 ; 1.60(2 \mathrm{H}, \mathrm{m})$ \\
\hline 13 & 37.9 & - & 37.5 & - & 43.6 & - \\
\hline 14 & 157.7 & - & 158.0 & - & 51.3 & - \\
\hline 15 & 117.3 & $5.56(1 \mathrm{H}, \mathrm{d}, 3.25)$ & 116.8 & $5.55(1 \mathrm{H}, \mathrm{dd}, 3)$ & 34.1 & $1.43 ; 1.45(2 \mathrm{H}, \mathrm{m})$ \\
\hline 16 & 36.8 & $1.32 ; 1.26(2 \mathrm{H}, \mathrm{m}, 3.25)$ & 37.7 & $1.63 ; 1.93(2 \mathrm{H}, \mathrm{dd}, 3)$ & 27.0 & $2.56 ; 2.44(2 \mathrm{H}, \mathrm{m})$ \\
\hline 17 & 37.7 & - & 35.7 & - & 52.9 & $1.47(1 \mathrm{H}, \mathrm{m})$ \\
\hline 18 & 48.9 & $1.02(1 \mathrm{H}, \mathrm{dd}, 4.5)$ & 48.7 & $0.97(1 \mathrm{H}, \mathrm{m}, 5)$ & 21.9 & $0.91(3 \mathrm{H}, \mathrm{s})$ \\
\hline 19 & 40.7 & $2.07 ; 1.31(2 \mathrm{H}, \mathrm{m}, 4.5)$ & 36.6 & $1.33 ; 0.97(2 \mathrm{H}, \mathrm{m})$ & 13.1 & $0.76(3 \mathrm{H}, \mathrm{s})$ \\
\hline 20 & 28.9 & - & 28.7 & - & 36.2 & $1.39(1 \mathrm{H}, \mathrm{m})$ \\
\hline 21 & 33.7 & $1.67 ; 1.57(2 \mathrm{H}, \mathrm{m})$ & 33.0 & $1.27 ; 1.35(2 \mathrm{H}, \mathrm{m})$ & 18.4 & $0.89(3 \mathrm{H}, \mathrm{d}, 5.5)$ \\
\hline 22 & 33.2 & $1.38 ; 1.24(2 \mathrm{H}, \mathrm{m})$ & 35.1 & $1.37 ; 1.01(2 \mathrm{H}, \mathrm{m})$ & 35.8 & $1.52 ; 1.14(2 \mathrm{H}, \mathrm{m})$ \\
\hline 23 & 26.2 & $1,08(3 \mathrm{H}, \mathrm{s})$ & 27.9 & $0.99(3 \mathrm{H}, \mathrm{s})$ & 28.3 & $1.95 ; 1.25(2 \mathrm{H}, \mathrm{m})$ \\
\hline 24 & 21.6 & $1.06(3 \mathrm{H}, \mathrm{s})$ & 15.4 & $0.82(3 \mathrm{H}, \mathrm{s})$ & 147.3 & $6.08(1 \mathrm{H}, \mathrm{s})$ \\
\hline 25 & 14.9 & $1.08(3 \mathrm{H}, \mathrm{s})$ & 15.4 & $0.94(3 \mathrm{H}, \mathrm{s})$ & 125.8 & - \\
\hline 26 & 30.0 & $0.83(3 \mathrm{H}, \mathrm{s})$ & 25.9 & $1.10(3 \mathrm{H}, \mathrm{s})$ & 172.7 & - \\
\hline 27 & 25.7 & $1.14(3 \mathrm{H}, \mathrm{s})$ & 21.3 & $0.92(3 \mathrm{H}, \mathrm{s})$ & 20.7 & $1.91(3 \mathrm{H}, \mathrm{s})$ \\
\hline 28 & 30.1 & $0.91(3 \mathrm{H}, \mathrm{s})$ & 29.8 & $0.83(3 \mathrm{H}, \mathrm{s})$ & 27.9 & $0.93(3 \mathrm{H}, \mathrm{s})$ \\
\hline 29 & 33.5 & $0.95(3 \mathrm{H}, \mathrm{s})$ & 33.3 & $0.96(3 \mathrm{H}, \mathrm{s})$ & 22.0 & $0.83(3 \mathrm{H}, \mathrm{s})$ \\
\hline 30 & 21.5 & $0.91(3 \mathrm{H}, \mathrm{s})$ & 29.9 & $0.92(3 \mathrm{H}, \mathrm{s})$ & 27.4 & $0.97(3 \mathrm{H}, \mathrm{s})$ \\
\hline
\end{tabular}

Overall, compounds 1 and $\mathbf{2}$ (Figure 1) were isolated for the first time from the genus Dysoxylum, while compound $\mathbf{3}$ was the first time from the corresponding species. The presence of euphan/tirucallane-type compounds like masticadienolic acid $\mathbf{3}$ have been widely reported from the genus Dysoxylum. Variations in tirucallane-type from the genus Dysoxylum generally occur through oxidation or epoxidation at side chain (Luo et al. 2000; Mohammad et al. 1999).

The cytotoxic effects of the three isolated compounds 1, 2, and $\mathbf{3}$ against MCF-7 breast cancer cell lines were investigated (SI.22). A 13 folds difference of 
cytotoxic effect was observed between compound $\mathbf{1}$ and 2 with the $\mathrm{IC}_{50} 792.9,59.6$ and $3.5 \mu \mathrm{M}$, respectively. According to the structure relationship, presumably due to the hydroxyl substituent (compound 2) which inhibits cancer cell lines much better than ketone group at $\mathrm{C}-3$ (compound 1). In contrast, the most potent cytotoxic compound against the cancer cell was possessed by compound 3 with $\mathrm{IC}_{50} 3.5 \mu \mathrm{M}$.

It was known that cytotoxic activity of an active compound against MCF7 cell lines is due to inhibition of aromatase targeting CYP19A1 (Shibahara et al. 2012). Based on molecular docking studies of cytotoxic tetracyclic triterpenoids typical compound such as,

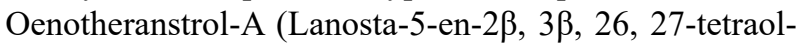
21-oic acid) and Oenotheranstrol-B (Lanosta-5-en-2 $\beta$, $3 \beta, 26$, 30-tetrol-21-oic acid) against the aromatase CYP19A1, the carboxylic acid and olefinic moieties were most probably responsible for the inhibition activity (Prakash et al. 2014). As compound 3 contained similar moieties, it is implied that the inhibition mechanism of the compound against the aromatase targeting CYP19A1 of MCF7 cell lines behaves in the same manner with those reported by Prakash et al. (2014). Thus, compound 3 was the most potent against MCF7 cell lines. Nevertheless, further molecular docking studies of compound $\mathbf{3}$ against the aromatase targeting CYP19A1 of MCF7 cell lines must be carried out to clarify the hypothesis.

\section{CONCLUSION}

Three triterpenoid compounds, taraxerone (1) and 18-epi-taraxerol (2), and masticadienolic acid (3), have been isolated for the first time from the stem barks of $D$. arborescens, and $D$. excelsum correspondingly. The $\mathrm{IC}_{50}$ values of compound $\mathbf{1}, \mathbf{2}$, and $\mathbf{3}$ against MCF7 breast cancer cell lines in vitro were 792.9, 59.6, and $3.5 \mu \mathrm{M}$, respectively. Further studies on phytochemistry, bioactivity and structure and activity relationships through bioinformatics of the two species are expected to increase Meliaceae plants potential in medical application.

\section{ACKNOWLEDGEMENTS}

This investigation was financially supported by Directorate General of Higher Education, Ministry of Science, Technology and Higher Education, Indonesia (Competence Grant, 2016-2017 by TM and RKDU 2018 by AZ). We are grateful to Tenny Putri Wikayani, Nurul Qomarilla, Cells and Tissues Culture Laboratory, Faculty of Medicine, Universitas Padjadjaran for MTT assay.

\section{REFERENCES}

Duh, C.Y., Wang, S.K. \& Chen, I.S. 2000. Cytotoxic prenyludesmane diterpenes from the fruits of Dysoxylum kuskusense. Journal of Natural Products 63(11): 15461547.

Fujioka, T., Yamamoto, M., Kashiwada, Y., Fuji, H., Mihashi, K., Ikeshiro, Y., Chen, I. \& Lee, K. 1998. Novel cytotoxic diterpenes from the stem of Dysoxylum kuskusense. Tetrahedron Letters 8: 3479-3482.Han, M.L., Zhao, J.X., Liu, H.C., Ni, G., Ding, J., Yang, S.P. \& Yue, J.M. 2015. Limonoids and triterpenoids from Dysoxylum mollissimum var glaberrimum. Journal of Natural Products 78(4): 754761.

Hu, J., Song, Y., Li, H., Mao, X., Zhao, Y., Shi, X. \& Yang, B. 2014. Antibacterial and cytotoxic triterpenoids from the ethanol extract of Dysoxylum densiflorum (Blume) Miq. Phytochemistry Letters 10: 219-223.

Kurimoto, S.I., Kashiwada, Y., Lee, K.H. \& Takaishi, Y. 2011. Triterpenes and a triterpene glucoside from Dysoxylum cumingianum. Phytochemistry 72: 2205-2211.

Lakshmi, V., Pandey, K. \& Agarwal, S.K. 2009. Bioactivity of the compounds in genus Dysoxylum. Acta Ecologica Sinica 29: $30-44$.

Liu, H., Heilmann, J., Rali, T. \& Sticher, O. 2001. New tirucallane-type triterpenes from Dysoxylum variabile. Journal of Natural Products 64: 159-163.

Luo, X., Wu, S., Ma, Y. \& Wu, D. 2000. Tirucallane triterpenoids from Dysoxylum hainanense. Phytochemistry 54(8): 801805.

Mabberley, D.J. 2008. 14. Dysoxylum Blume, Bijdr. 172. 1825. China. Fl. China 11: 125-129.

Makino, M., Motegi, T. \& Fujimoto, Y. 2003. Tirucallane-type triterpenes from Juliania adstringens. Phytochemistry 65: 891-896.

Mejin, M. 2009. Isolation, structural elucidation and antibacterial activity of the chemical constituents of Scaevola spinescens. Theses MSc. The University of Adelaide. Adelaide, South Australia (Unpublished).

Mohammad, K., Martin, M.T., Litaudon, M., Gaspard, C., Sévenet, T. \& Païs, M. 1999. Tirucallane triterpenes from Dysoxylum macranthum. Phytochemistry 52: 1461-1468.

Mosmann, T. 1983. Rapid colorimetric assay for cellular growth and survival: Application to proliferation and cytotoxicity assays. Journal of Immunological Methods 65(1-2): 55-63.

Morita, H., Nugroho, A.E., Nagakura, Y., Hirasawa, Y., Yoshida, H., Kaneda, T., Shirota, O. \& Ismail, I.S. 2014. Chrotacumines A-D, chromone alkaloids from Dysoxylum acutangulum with osteoclast differentiation inhibitory activity. Bioorganic \& Medicinal Chemistry Letter 24: 2437-2439.

Nugroho, A.E., Sugiura, R., Momota, T., Hirasawa, Y., Wong, C.P., Kaneda, T., Hadi, A.H.A. \& Morita, H. 2015. Dysosesquiflorins A and B, sesquiterpenoids from Dysoxylum densiflorum. Journal of Natural Medicines 69(3): 411-415.

Prakash, O., Ahmad, A., Tripathi, V.K., Tandon, S. \& Pant, A.B. 2014. In silico assay development for screening of tetracyclic triterpenoids as anticancer agents against human breast cancer cell line MCF7. PLOS ONE 9(11): e111049.

Ragasa, C.Y., Ebajo Jr., V.D., Antonio, S., Ng, M.M., De Los, R. \& Shen, C.C. 2014. Chemical constituents of Strongylodon macrobotrys. Der Pharma Chemica 6(6): 366-373.

Shibahara, Y., Miki, Y., Onodera, Y., Hata, S. \& Chan, M.S. 2012. Aromatase inhibitor treatment of breast cancer cells increases the expression of let-7f, amicroRNA targeting CYP19A1. The Journal of Pathology 227: 357-366.

Unang, S., Wiro, N., Supriatno, S., Rani, M., Ace, T.H., Desi, H., Nurlelasari. \& Yoshihito, S. 2019. Cytotoxic triterpenoids 
from the bark of Chisocheton patens Blume (Meliaceae). Phytochemistry Letters 30: 81-87.

Wah, L.K., Abas, F., Cordell, G.A., Ito, H. \& Ismail, I.S. 2013. Steroids from Dysoxylum grande (Meliaceae) leaves. Steroids 78: 210-219.

Zhou, B., Shen, Y., Wu, Y., Leng, Y. \& Yue, J.M. 2015. Limonoids with $11 \beta$-hydroxysteroid dehydrogenase type 1 inhibitory activities from Dysoxylum mollisimum. Journal of Natural Products 78(8): 2116-2122.

Achmad Zainuddin, Sylvia Rachmawati Meilanie, Darwati, Kurniawan, Nurlelasari, Tati Herlina, Adrian Rizky Saputra, Jamaludin Al Anshori \& Tri Mayanti*

Department of Chemistry

Faculty of Mathematics and Natural Sciences

Universitas Padjadjaran

Jl. Raya Bandung-Sumedang Km 21 Jatinangor 45363

Indonesia
Jamaludin Al Anshori

Laboratory of Applied Chemistry and Services

Faculty of Mathematics and Natural Sciences

Universitas Padjadjaran

Jl. Raya Bandung-Sumedang Km 21 Jatinangor 45363

Indonesia

*Corresponding author; email: t.mayanti@unpad.ac.id

Received: 11 February 2019

Accepted: 19 January 2020 